\title{
Effect of Type of Planting Materials and Rooting Media on Yield and Economics of Suru Sugarcane (Saccharum officinarum L.)
}

\author{
A.D. Mote*, S.B. Gangawane, G.B. Shendage, P.P. Sarawale and Bhru Lal Kumhar \\ Department of Agronomy, College of Agriculture, Dapoli, Dr. Balasaheb SawantKonkan Krishi \\ Vidyapeeth, Dapoli- 415712 Maharashtra, India \\ *Corresponding author
}

\begin{tabular}{|c|c|}
\hline & A B S T R A C T \\
\hline & $\begin{array}{l}\text { The investigation entitled "Effects of type of planting materials and rooting media on yield } \\
\text { and economics of suru sugarcane" during the season 2013-14 at Agronomy Farm, College }\end{array}$ \\
\hline & $\begin{array}{l}\text { of Agriculture, Dapoli. The experiment was laid out in factorial randomized block design } \\
\text { (FRBD) replicated thrice. Factor A comprised two types of planting materials viz., single }\end{array}$ \\
\hline $\begin{array}{l}\text { Yield, } \\
\text { Planting, } \\
\text { Sugarcane } \\
\text { and Cocopeat. }\end{array}$ & $\begin{array}{l}\text { bud setts (BS) and scooped bud chips }(\mathrm{BC}) \text { and factor } \mathrm{B} \text { compared of seven types of } \\
\text { rooting media viz: } \mathrm{B}_{1^{-}} \text {- Soil alone }(\mathrm{Sa}), \mathrm{B}_{2^{-}} \text {Cocopeat alone }(\mathrm{Ca}), \mathrm{B}_{3^{-}} \text {Cocopeat } 50 \%+ \\
\text { Vermicompost } 50 \% \text { by weight }(\mathrm{CV}), \mathrm{B}_{4^{-}}-\mathrm{B}_{3}+\mathrm{PSB}(\mathrm{CV}+\mathrm{P}), \mathrm{B}_{5^{-}} \mathrm{B}_{3}+\text { Acetobacter } \\
(\mathrm{CV}+\mathrm{Ac}), \mathrm{B}_{6^{-}}-\mathrm{B}_{3}+\text { Trichoderma viride }(\mathrm{CV}+\mathrm{T}), \mathrm{B}_{7^{-}} \mathrm{B}_{3}+\mathrm{PSB}+\text { Acetobacter }+\end{array}$ \\
\hline Article Info & Trichoderma viride $(\mathrm{CV}+\mathrm{Al})$ and $\mathrm{T}_{15^{-}} \mathrm{An}$ additional treatment of conventional in situ \\
\hline $\begin{array}{l}\text { Accepted: } \\
12 \text { March } 2017 \\
\text { Available Online: } \\
10 \text { April } 2017\end{array}$ & $\begin{array}{l}\text { revealed that, the use of cocopeat }+ \text { vermicompost }+ \text { acetobacter }\left[B_{5}(B S-C V+A c)\right] \text { and } \\
\text { cocopeat }+ \text { vermicompost }+ \text { PSB }\left[\mathrm{B}_{4}(\mathrm{BS}+\mathrm{CV}+\mathrm{P})\right] \text { as a rooting media recorded } \\
\text { significantly higher cane yield }(\mathrm{t} / \mathrm{ha}) \text {, green top weight }(\mathrm{t} / \mathrm{ha}) \text { and weight of trash }(\mathrm{t} / \mathrm{ha}) \text {. } \\
\text { Treatment } \mathrm{B}_{5} \text { gave the significantly highest gross returns }\left(\mathrm{Rs} .332684 .2 \mathrm{ha}^{-1}\right) \text {, net returns }\end{array}$ \\
\hline & $\begin{array}{l}\left.\text { (Rs. } 124916.99 \mathrm{ha}^{-1}\right) \text { and } \mathrm{B}: \mathrm{C} \text { ratio }(1.60) \text { as compared to all other treatments but } \\
\text { remained at par with treatment } \mathrm{B}_{4} \text {. }\end{array}$ \\
\hline
\end{tabular}

\section{Introduction}

Sugarcane is an important commercial multipurpose crop that provides sugar and jaggery as by-products with ecological sustainability. It is also a renewable, natural agricultural resource. Sugarcane juice is used for making white sugar, brown sugar (Khandsari), Jaggery (Gul) and ethanol. The main by-products after the juice extraction are molasses and bagasse. The cultivation of sugarcane dates back to the Vedic period. The most ancient reference to sugarcane is in Athervaveda which is 4,000 years old and the word sugar is derived from the Sanskrit word
Sarkara. In the 1400-1500 in India, cows belonging to the Sultan of Mandu were fed with sugarcane to make their milk sweet for use in puddings.

Sugarcane is one of the important crops in contributing to the country's economy and farmer's livelihood development. In India, sugar is 550 billion rupees worth industry, supporting more than 50 million farmers. There is a growing demand for sugar in India. Hence, there will be more and more stress on the sugarcane eco-system in future. The 
present scenario of cane cultivation is not sustainable enough to meet this demand as the input and labour costs are increasing and the national mean cane productivity is at $66.9 \mathrm{t} \mathrm{ha}^{-1}$ only. So, it is necessary to improve the cane productivity in a sustainable way with minimum usage of inputs through some alternate methods on the principles of "more with less".

Sugarcane yields in some areas of Uttar Pradesh were moderate, due to late planting and excessive rain. However, western and southern Indian states tended to benefit from timely and evenly distributed monsoon rains, which increased cane productivity in those regions. With the rise in cane production, total centrifugal sugar production in 2013-14 is also revised up from 25.4 MMT to 27 MMT, mostly due to higher than expected sugar production levels, particularly from Maharashtra and Karnataka. Additionally, favourable monsoon conditions have improved India's overall sugarcane recovery to 10.25 percent, an increase of 0.25 percent over last year (Anonymous, 2013-14).

Indian Institute of Sugarcane Research, Lucknow evolved a planting method namely, 'Spaced transplanting technique - STP' (Anonymous, 1976; Srivastava et al., 2006). In this method single bud settlings are raised in nursery from single eye setts and transplanted in actual field after about four weeks when settlings do have 2 to 3 green leaves. Transplanting single bud settlings at 30 and $60 \mathrm{~cm}$ distance within a row gave fewer yields of 176.70 and 166.77 $\mathrm{MT} \mathrm{ha}^{-1}$ respectively than that of conventional method of planting three budded setts which yielded 183.80 MT ha $\mathrm{MT}^{-1}$. The results of the trials conducted at Lucknow, Pantnagar, and Shahajanpur under All India Co-ordinated Research Project on Sugarcane showed that, STP method produced less yield than conventional method (Anonymous, 1977-78).

\section{Materials and Methods}

The field experiment was conducted during the year 2013-14 on seasonal sugarcane at the Agronomy Farm, College of Agriculture, Dapoli in plot number 54 of the ' $C$ ' block. The site was selected on the basis of suitability of soil for growing sugarcane. Media were prepared as per the treatments. For the treatments $\mathrm{T}_{1}$ and $\mathrm{T}_{8}$, soil from the experimental plot itself was used as medium for raising settlings from single bud setts and single bud chips respectively. In case of the treatments $\mathrm{T}_{2}$ and $\mathrm{T}_{9}$ cocopeat alone was used. For the treatment $T_{3}$ and $T_{10}$ media were prepared by mixing cocopeat and vermicompost in equal proportion on weight basis $12.5 \mathrm{~kg}+12.5 \mathrm{~kg}$ for single bud setts and $7.5 \mathrm{~kg}+7.5 \mathrm{~kg}$ for scooped bud chips. In case the treatments viz. $\mathrm{T}_{4}$ and $\mathrm{T}_{11}, \mathrm{~T}_{5}$ and $\mathrm{T}_{12}, \mathrm{~T}_{6}$ and $\mathrm{T}_{13}$ bacterial and fungal inoculants viz., PSB (Bacillus megatherium), Acetobacter (Glucanoacetobacter diazotrophicus) and Trichoderma viride were added @ $5 \mathrm{gKg}^{-1}$ medium prepared as per treatment.

Seed canes of Sugarcane variety CoM 0265 having age of 10 months was obtained from Regional Sugarcane and Jaggery Research Station, Kolhapur were used. Single bud setts were prepared with the help of sharp knife by cutting seed canes $2.5 \mathrm{~cm}$ above the bud and $5-6 \mathrm{~cm}$ below the bud. These single bud setts were sown in plastic trays of $56 \mathrm{~cm} \times 36 \mathrm{~cm}$ size having 42 rectangular cups each with 70 mm length, $50 \mathrm{~mm}$ width and $75 \mathrm{~mm}$ depth. Using the same source of seed canes, scooped bud chips were obtained by separating each bud keeping the distance of 20 to $25 \mathrm{~mm}$ all around the bud with the help of specially prepared bud scooping machine. For raising settlings from scooped bud chips plastic trays of $56 \mathrm{~cm}$ x $36 \mathrm{~cm}$ size having 60 circular cups each with $50 \mathrm{~mm}$ circumference and $62.5 \mathrm{~mm}$ depth were used. 
The recommended dose of fertilizer viz., 250 $\mathrm{kg} \mathrm{N}, 125 \mathrm{~kg} \mathrm{P}_{2} \mathrm{O}_{5}$ and $125 \mathrm{~kg} \mathrm{~K}_{2} \mathrm{O} \mathrm{ha}^{-1}$ was used for field experiment. At the time of planting 10 per cent dose of Nitrogen and entire dose of $\mathrm{P}_{2} \mathrm{O}_{5}$ and $\mathrm{K}_{2} \mathrm{O}$ were applied by placement method just before planting of sugarcane crop. Remaining $\mathrm{N}$ were applied in three split doses@ $@ 40,10$ and 40 per cent at an interval of six weeks from each preceding dose. When settlings attained an age of 28 days, they were transplanted in ridges and furrows spaced $90 \mathrm{~cm}$ apart keeping the distance of $30 \mathrm{~cm}$ between two hills in a row. The other common package of practices was followed time to time and periodical growth observations were recorded.

\section{Results and Discussion}

Effect of type of planting materials and rooting media on yield of suru sugarcane

The main objective of the agronomist is to increase the economic yield of crop. The use of cocopeat + vermicompost + acetobacter

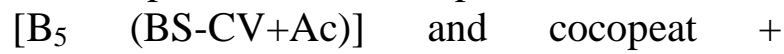
vermicompost $+\mathrm{PSB}\left[\mathrm{B}_{4}(\mathrm{BS}+\mathrm{CV}+\mathrm{P})\right]$ as a rooting media recorded significantly higher cane yield (t/ha), green top weight (t/ha) and weight of trash ( $\mathrm{t} / \mathrm{ha}$ ) as compared to other treatments except treatment $\mathrm{B}_{4}$, the yield of suru sugarcane are presented in table 1.

Table.1 Effect of type of planting materials and rooting media on yield of suru sugarcane

\begin{tabular}{|c|c|c|c|}
\hline Treatments & $\begin{array}{c}\text { Cane yield } \\
\left(\mathrm{t} \mathrm{ha}^{-1}\right)\end{array}$ & $\begin{array}{c}\text { Green top } \\
\text { Weight }\left(\mathrm{t} \mathrm{ha}^{-1}\right)\end{array}$ & $\begin{array}{c}\text { Weight of trash } \\
\left(t \text { ha }^{-1}\right)\end{array}$ \\
\hline \multicolumn{4}{|c|}{ Factor A- Type of planting material } \\
\hline $\mathbf{A}_{1}-$ Single bud setts & 111.49 & 20.06 & 5.09 \\
\hline $\mathbf{A}_{2}-$ Scooped bud chips & 108.38 & 19.23 & 5.07 \\
\hline S.Em. \pm & 2.83 & 0.47 & 0.22 \\
\hline C.D. at $5 \%$ & NS & NS & NS \\
\hline \multicolumn{4}{|l|}{ Factor B- Rooting media } \\
\hline $\mathbf{B}_{1}: \mathrm{Sa}$ & 82.29 & 14.39 & 3.58 \\
\hline $\mathbf{B}_{2}: \mathrm{Ca}$ & 89.87 & 16.51 & 4.08 \\
\hline $\mathbf{B}_{3}: \mathrm{CV}$ & 96.22 & 19.01 & 4.55 \\
\hline $\mathbf{B}_{4}: \mathrm{CV}+\mathrm{P}$ & 133.52 & 21.78 & 6.21 \\
\hline $\mathbf{B}_{5}: \mathrm{CV}+\mathrm{Ac}$ & 134.68 & 22.92 & 6.42 \\
\hline $\mathbf{B}_{6}: \mathrm{CV}+\mathrm{T}$ & 119.17 & 21.87 & 5.61 \\
\hline $\mathbf{B}_{7}: \mathrm{CV}+\mathrm{Al}$ & 112.80 & 20.06 & 5.11 \\
\hline S.Em. \pm & 1.85 & 0.31 & 0.11 \\
\hline C.D. at $5 \%$ & 5.37 & 0.89 & 0.40 \\
\hline \multicolumn{4}{|l|}{ Interaction effects } \\
\hline S.Ed. \pm & 4.91 & 0.81 & 0.38 \\
\hline C.D. at $5 \%$ & NS & NS & $\mathrm{NS}$ \\
\hline General mean & 109.94 & 19.65 & 5.08 \\
\hline \multicolumn{4}{|l|}{ CIP v/s rest } \\
\hline Mean of factors A and B (Rest) & 109.94 & 19.65 & 5.08 \\
\hline CIP mean & 115.93 & 19.68 & 5.27 \\
\hline S.Ed. \pm & 5.08 & 0.84 & 0.42 \\
\hline C.D. at $5 \%$ & NS & NS & NS \\
\hline
\end{tabular}


Table.2 Effect of type of planting materials and rooting media on economics of suru sugarcane

\begin{tabular}{|c|c|c|c|c|}
\hline Treatments & $\begin{array}{c}\text { Total cost } \\
\left(\text { Rs.ha }^{-1}\right)\end{array}$ & $\begin{array}{c}\text { Gross income } \\
\left(\text { Rs.ha }^{-1}\right)\end{array}$ & $\begin{array}{c}\text { Net income } \\
\left(\text { Rs.ha }^{-1}\right)\end{array}$ & B:C ratio \\
\hline \multicolumn{5}{|c|}{ Factor A- Type of planting material } \\
\hline $\mathbf{A}_{1}-$ Single bud setts & 207259.27 & 276023.36 & 68764.09 & 1.33 \\
\hline $\mathbf{A}_{2}-$ Scooped bud chips & 199828.64 & 268042.44 & 68213.81 & 1.34 \\
\hline S.Em. \pm & 4427.3353 & 6453.56 & 6453.56 & - \\
\hline C.D. at $5 \%$ & $\mathrm{NS}$ & $\mathrm{NS}$ & $\mathrm{NS}$ & - \\
\hline \multicolumn{5}{|l|}{ Factor B- Rootingmedia } \\
\hline $\mathbf{B}_{\mathbf{1}}: \mathrm{Sa}$ & 193136.68 & 203664.51 & 10527.83 & 1.05 \\
\hline $\mathbf{B}_{2}: \mathrm{Ca}$ & 198959.30 & 223222.17 & 24262.87 & 1.12 \\
\hline $\mathbf{B}_{3}: \mathrm{CV}$ & 203885.24 & 240307.41 & 36422.17 & 1.18 \\
\hline $\mathbf{B}_{\mathbf{4}}: \mathrm{CV}+\mathrm{P}$ & 207787.48 & 328882.77 & 121095.29 & 1.58 \\
\hline $\mathbf{B}_{5}: \mathrm{CV}+\mathrm{Ac}$ & 207767.18 & 332684.17 & 124916.99 & 1.60 \\
\hline $\mathbf{B}_{6}: \mathrm{CV}+\mathrm{T}$ & 206372.28 & 295972.03 & 89599.75 & 1.43 \\
\hline $\mathbf{B}_{7}: \mathrm{CV}+\mathrm{Al}$ & 206899.50 & 279497.26 & 72597.76 & 1.35 \\
\hline S.Em. \pm & 3756.52 & 4224.84 & 4224.84 & - \\
\hline C.D. at $5 \%$ & 11556.36 & 12238.89 & 12238.89 & - \\
\hline \multicolumn{5}{|l|}{ Interaction effects } \\
\hline S.Ed. \pm & 6876.12 & 11177.89 & 11177.89 & - \\
\hline C.D. at $5 \%$ & $\mathrm{NS}$ & $\mathrm{NS}$ & NS & - \\
\hline General mean & 203543.95 & 272032.90 & 68488.95 & 1.33 \\
\hline \multicolumn{5}{|l|}{ CIP v/s rest } \\
\hline Mean of factors A and B(Rest) & 203543.95 & 272032.90 & 68488.95 & 1.33 \\
\hline CIP mean & 209155.12 & 286421.75 & 77266.63 & 1.37 \\
\hline S.Ed. \pm & 6899.56 & 11570.21 & 11570.21 & - \\
\hline C.D. at $5 \%$ & $\mathrm{NS}$ & NS & NS & - \\
\hline
\end{tabular}


The application of acetobacter and phosphate solubilizing bacteria increased the cane yield due to acetobacter phosphorus increase the dry and fresh weight of sugarcane and it also helps to increase the nutrient uptake, growth promoting substance and synergetic interaction with other soil beneficial microorganisms which enhance the yield of sugarcane. The significant response of acetobactor and PSB on these characters has also been reported by Jaykumar and Thangaraju (1996), Muthukumarsamy et al., (1994) and Mahadevi et al., (1991).

Effect of type of planting materials and rooting media on economics of suru sugarcane

The data presented in table 2 showed that, the higher total cost of production was recorded in treatment $\mathrm{B}_{4}(\mathrm{CV}+\mathrm{P})$ which was Rs. 207787.48ha ${ }^{-1}$ whereas, the lowest cost of production was recorded in the treatment $\mathrm{B}_{1}$ (Sa) that of Rs. $193136.68 \mathrm{ha}^{-1}$. The highest gross income (Rs. 332684.17ha ${ }^{-1}$ ), net income (Rs. 124916.99 $\mathrm{ha}^{-1}$ ) and B:C (1.63) ratio was recorded by the treatment $\mathrm{B}_{5}(\mathrm{CV}+\mathrm{Ac})$. The above observations are in accordance with Narendranath (2000), Radha et al., (2010).

In conclusion, from the results of the present investigation it can be concluded that, the sugarcane crop should be grown with Single bud setts along with cocopeat + vermicompost mixture in 1:1 proportion and inoculated with acetobacter as a rooting media for obtaining higher yield, net returns and B: $\mathrm{C}$ ratio.

\section{References}

Anonymous. $1976 . \quad$ Circular No.
SDS/3675/11704-Q. 2 dated 26th April 1976 from Sugarcane Development Officer, Department of Agriculture, M.S. Pune-1.

Anonymous. 1977-78. Technical Report of All India Co-ordinated Research Project on Sugarcane, Trial on Agronomy of late planting of sugarcane pp. 5 -8.

Anonymous. 2013-14. Technical Report of All India Co-ordinated Research Project on Sugarcane. Trial on Agronomy of late planting of sugarcane pp. $7-12$.

Jayakumar, P. and Thangaraju, M. 1996. Biofertilizers of sugarcane. TNAU Newslett., 26: 1-2.

Madhavi, D., C.R. Reddy, P.M. Reddy, C.L.K. Reddy, K.R. Reddy and K.H.P. Reddy. 1991. Correlation studies in sugarcane. Co-op. Sugar, 22(6): 379-381.

Muthukumarsamy, R., R. Revati and Solayappan. 1994. Co-op. Sugar, 25: 287-290.

Narendranath, M. 2000. Cost effectiveness of transplanting nursery raised sugarcane bud-chip plants on commercial sugar plantations. Ind, J. Agron., pp. 332-333.

Radha, J., Srivastava, S., Solomon, S., Shrivastava, A.K. and Chandra, A. 2010. Impact of excess zinc on growth parameters cell division, nutrient accumulation, photosynthetic pigments and oxidative stress of sugarcane (Saccharum spp). Acta Physiol. Plant, 32: 979- 986.

Shrivastava, T.K., Pandey, M.B. and Awasthi, S.K. 2006. Effect of planting methods and nutrient manegment on growth, yield and rejuation of declined sugarcane (Saccharum complex hybrid). Indian J. Agri. Sci., 01(76): pp.103- 107.

\section{How to cite this article:}

Mote, A.D., S.B. Gangawane, G.B. Shendage, P.P. Sarawale and Bhru Lal Kumhar. 2017. Effect of Type of Planting Materials and Rooting Media on Yield and Economics of Suru Sugarcane (Saccharum officinarum L.). Int.J.Curr.Microbiol.App.Sci. 6(4): 1280-1284.

doi: https://doi.org/10.20546/ijcmas.2017.604.156 